\title{
FAKTOR YANG BERHUBUNGAN TOTAL FOOD LOSS AND WASTE (FLW) PADA KARYAWAN PT. CJM SELAMA PANDEMI COVID-19
}

\author{
Factors Related to Total Food Loss And Waste (FLW) in Employees of PT. \\ Camiloplas Jaya Makmur during The Covid-19 Pandemic \\ Nur Azizah $^{1}$, Prita Dhyani Swamilaksita ${ }^{1}$, Harna $^{1}$, Putri Ronitawati ${ }^{2}$ \\ ${ }^{1}$ Program Studi Ilmu Gizi, Fakultas Ilmu-ilmu Kesehatan, Universitas Esa Unggul \\ ${ }^{2}$ Program Studi Dietisien, Fakultas Ilmu-ilmu Kesehatan, Universitas Esa Unggul \\ E-mail: prita.dhyani@esaunggul.ac.id
}

\begin{abstract}
The implementation of large-scale social restrictions during the COVID-19 pandemic has made employees do their work at home so they spend more time ordering food online. This will lead to bad habits that cause food loss and waste $(F L W)$ because the food available at home if not consumed will be wasted. This study aims to determine the factors related to total food loss and waste (FLW) in PT CJM employees during the COVID-19 pandemic. The research method is quantitative with a design cross-sectional. Engineering samples total sampling.The analysis of this study used the chi-square. Data were collected using the FLW behavior questionnaire and the form estimated food record $3 \times 24$ hours. The results showed that there was a relationship between age $(p=0.000, O R=14,385)$ and gender $(p=0.000$, $O R=20,855)$ to total food loss and waste $(F L W)$ but there was no relationship between knowledge $(p=0,139)$, income $(p=0,826)$, food selection $(p=0,332)$, lifestyle $(p=0,486)$, frequency of eating $(p=0,492)$ and meal times including breakfast $(p=1,000)$, lunch $(p=0,346)$, and dinner $(p=0.476$ to the total food loss and waste $(F L W)$. Therefore, employees are expected to be wiser in ordering food online and endeavor to make a list of food to be purchased in order to minimize the occurrence of food loss and waste (FLW).
\end{abstract}

Keywords: Covid-19, factors, food loss and waste, employees

\begin{abstract}
ABSTRAK
Adanya pemberlakuan pembatasan sosial berskala besar selama pandemi COVID-19 membuat karyawan melakukan pekerjaan dirumah sehingga lebih sering menghabiskan waktunya dengan melakukan pemesanan makanan online. Hal ini akan menimbulkan kebiasaan buruk yaitu menyebabkan terjadinya food loss and waste (FLW) karena makanan yang tersedia dirumah jika tidak dikonsumsi akan terbuang. Penelitian ini bertujuan untuk mengetahui faktor yang berhubungan total food loss and waste (FLW) pada karyawan PT CJM Selama Pandemi COVID-19. Metode penelitian adalah kuantitatif dengan desain cross-sectional. Teknik sampel total sampling. Analisis penelitian ini menggunakan chi-square. Data dikumpulkan menggunakan kuesioner perilaku FLW dan form estimated food record $3 \times 24$ jam. Hasil penelitian terdapat hubungan umur $(\mathrm{p}=0,000, \mathrm{OR}=14.385)$ dan jenis kelamin $(\mathrm{p}=0,000, \mathrm{OR}=20.855)$ terhadap total food loss and waste (FLW) tetapi tidak ada hubungan pengetahuan $(\mathrm{p}=0,139)$, pendapatan $(\mathrm{p}=0,826)$, pemilihan makan $(\mathrm{p}=0,332)$, gaya hidup $(\mathrm{p}=0,486)$, frekuensi makan $(\mathrm{p}=0,492)$ dan waktu makan meliputi sarapan pagi $(\mathrm{p}=1,000)$, makan siang $(\mathrm{p}=0,346)$, dan makan malam $(\mathrm{p}=0,476)$ terhadap total food loss and waste $(\mathrm{FLW})$. Oleh karena itu, karyawan diharapkan lebih bijak dalam melakukan pemesanan makanan secara online dan diusahakan membuat daftar list makanan yang akan dibeli agar meminimalisir terjadinya food loss and waste (FLW).
\end{abstract}

Kata Kunci: Covid-19, faktor, food loss and waste, karyawan 


\section{PENDAHULUAN}

Indonesia berada di peringkat kedua tertinggi kasus COVID-19 di ASEAN pada bulan Agustus 2020 (Kementrian Kesehatan RI, 2020). Oleh karena itu, pemerintah mulai melakukan pembatasan sosial berskala besar (PSBB) selama pandemi COVID-19 tujuannya untuk mengurangi penyebaran virus agar tidak semakin meningkat (Martinez-Ferran,et al, 2020). Hal ini akan berdampak di bidang pangan khususnya ketahanan pangan karena masyarakat diharuskan untuk mengurangi kontak fisik serta melakukan pekerjaan dari rumah sehingga akan akan berpengaruh pada produksi, distribusi dan konsumsi pangan.

Untuk itu upaya mewujudkan ketahanan pangan dengan mengurangi kehilangan pangan (food loss) dan makanan tak terkonsumsi (food waste). Food loss and waste merupakan sisa makanan yang dimulai dari tahap belanja, penyimpanan bahan makanan, pengolahan, konsumsi dan penyimpanan makanan. Jika masyarakat masih banyak yang melakukan food loss and waste maka akan menimbulkan dampak yang besar bagi lingkungan diantaranya dapat menghasilkan gas metana sehingga berpotensi sebagai gas rumah kaca, meningkatkan pemanasan global dan permintaan tinggi pada lahan pertanian (Graham-Rowe, E., Jessop, D. C., \& Sparks, 2015). Pada aspek gizi akan menyebabkan kurangnya jumlah zat gizi yang tersedia. Ada beberapa kelompok makanan yang banyak menghasilkan food loss and waste antara lain makanan yang mengandung susu dan lemak. Rata-rata jumlah zat gizi yang terbuang berkisar $102 \mathrm{kkal}, 7$ gr protein, 1,9 gr serat, 75,7 mg kalsium (Pavone et al., 2019).

Berdasarkan data Economist Intelligence Unit tahun 2016 bahwa Indonesia penyumbang terbesar kedua sisa makanan, yaitu sekitar 3000 kilogram makanan per orang setiap tahun. Menurut data SIPSN (Sistem Informasi Pengelolaan Sampah Nasional) tahun 2020 di wilayah Kota Tangerang menghasilkan sisa makanan sebesar $61.38 \%$ dimana termasuk kedalam urutan kedua di provinsi Banten.

Karyawan merupakan seseorang yang bekerja di lembaga, kantor atau perusahaan secara permanen untuk menghasilkan upah atau gaji (Sukmi Natalia, 2018). Selama pandemi Covid-19 karyawan sudah mulai diberlakukannya untuk WFH (Work From Home). Hal tersebut ada kaitanya dengan kebiasaan karyawan selama pandemi pada saat waktu senggang mereka lebih sering menghabiskan waktunya untuk memesan makanan via online dikarenakan selama melakukan Work From Home (WFH) mereka mulai merasakan jenuh atau bosan dengan masakan rumah (Kartika, 2020). 
Menurut penelitian (Iisnawatia et al., 2019) menunjukkan bahwa 35\% seseorang yang berusia 25-49 tahun dengan status pekerjaannya sebagai karyawan swasta dan Pegawai Negeri Sipil (PNS) selama masa pandemic mereka lebih suka melakukan pemesanan online. Hal itu memungkinkan dapat menyebabkan terjadinya food waste dikarenakan makanan yang tersedia di rumah jika tidak dikonsumsi akan terbuang sia-sia.

Menurut hasil penelitian Kanopi FEB UI bahwa rata-rata responden laki-laki lebih cenderung menghabiskan makanan yang lebih banyak daripada responden wanita (Universitas Indonesia, 2019). Hal itu disebabkan karena pria memiliki ukuran gigitan lebih besar daripada wanita sehingga proses dalam mengunyah makanan akan lebih cepat (Ariesta, 2019). Selain itu, Hasil penelitian Mandasari, 2018 menunjukkan $-19$.

\section{METODE}

\section{Desain, Tempat, dan Waktu}

Desain penelitian ini merupakan penelitian kuantitatif dengan desain cross sectional untuk mengetahui faktor yang berhubungan total food loss and waste (FLW) pada karyawan PT CJM Selama Pandemi COVID-19. Seluruh rangkaian kegiatan mulai dari survey lokasi sampai dengan pengambilan data dilakukan dari bulan Maret- bahwa hasil dari food waste berkisar 47,05 gram per orang per bulan (sama dengan 564,62 gram per orang per tahun) dan secara signifikan faktor yang mempengaruhi food waste adalah frekuensi makan dengan nilai 0,006 dan jenis kelamin dengan nilai 0,035 . Nagelkerke R Square menunjukkan hasil dari food waste berkisar 18,7 \% yaitu frekuensi makan, biaya hidup, frekuensi makan diluar dan jenis kelamin (Mandasari, 2018).

Berdasarkan uraian diatas peneliti tertarik untuk melakukan penelitian food waste yang dihasilkan dari kebiasaan seseorang tidak menghabiskan makanan yang dikonsumsi, Maka peneliti akan memulai dari wilayah terkecil dahulu untuk mengetahui faktor yang berhubungan total food loss and waste (FLW) pada Karyawan PT CJM Selama Pandemi COVID

Juni 2021. Penelitian ini dilakukan di PT CJM Telagasari, Cikupa, Kabupaten Tangerang.

\section{Jumlah dan Cara Pengambilan Sampel}

Populasi dari penelitian ini adalah seluruh Karyawan aktif PT CJM, Telagasari, Kabupaten Tangerang. Sedangkan untuk sampelnya adalah sebanyak 84 karyawan. Pengambilan sampel menggunakan teknik 
total sampling yang memiliki kriteria eksklusi responden keluar atau berhenti saat penelitian, melakukan diet tertentu, berpuasa dan picky eater sementara kriteria inklusi yaitu bersedia

\section{Cara Pengumpulan Data}

Pengumpulan data dimulai dengan memberikan penjelasan dan responden menandatangani informed consent yang telah diberikan. Setelahnya dilakukan pengisian kuesioner dan wawancara mengenai karakteristik karyawan seperti usia yang dikategorikan menjadi dewasa awal yaitu 1923 tahun diberikan skor 2 dan dewasa akhir yaitu $\geq 24$ tahun diberikan skor 1 , jenis kelamin dikategorikan jika perempuan diberikan skor 2 dan laki-laki diberikan skor 1, pengetahuan terkait food loss and waste terdiri dari 10 pertanyaan dengan pilihan jawaban benar, salah dan tidak tahu kemudian hasil jawaban akan dikategorikan menjadi baik (>75\%), cukup (56-74\%) dan kurang baik (<55\%), faktor ekonomi seperti pendapatan dikategorikan menjadi tinggi yaitu lebih dari Rp.3.800.000 dan rendah kurang dari Rp.3.800.000, faktor sosial seperti pemilihan makan terdiri dari 8 pertanyaan dengan pilihan jawaban sering, kadang, tidak pernah kemudian hasil skor akan dikategorikan menjadi baik jika nilai skor lebih dari $50 \%$ dan kurang baik jika nilai skor kurang dari sama dengan 50\% sedangkan gaya hidup terdiri dari 5 pertanyaan dengan pilihan jawaban setuju dan tidak setuju mengikuti penelitian sampai selesai, dalam keadaan sehat jasmani dan rohani, berusia 1940 tahun.

kemudian hasil skor akan dikategorikan menjadi baik jika nilai skor lebih dari sama dengan $75 \%$, cukup jika nilai skor 56-74\%, dan kurang baik jika nilai skor kurang dari $55 \%$, untuk faktor perilaku seperti frekuensi makan terdiri dari 5 pertanyaan dengan pilihan jawaban sering, jarang, tidak pernah kemudian hasil skor akan dikategorikan menjadi baik jika nilai skor lebih dari $50 \%$ dan kurang baik jika nilai skor kurang dari sama dengan $50 \%$, waktu makan diberikan 3 pertanyaan kemudian hasilnya akan dikategorikan menjadi sarapan pagi mulai dari 06.00-08.00 am, makan siang 12.00-13.00 pm dan makan malam 18.00-20.00 pm. Di akhir sesi, responden diberikan formulir estimated food record yang akan ditinggalkan selama $3 \times 24$ jam. Masing-masing pertanyaan kuesioner dan formulir estimated food record sudah dilakukan uji validitas. Responden akan menulis sisa makanan yang dilakukan dua hari saat weekdays dan satu hari pada weekend mulai dari sarapan pagi hingga makan malam baik itu makanan jadi ataupun makanan yang dibeli dari luar. Sisa makanan yang ditulis adalah sisa makanan yang dikonsumsi oleh responden. 


\section{Instrumen Penelitian}

Sumber data menggunakan data primer yang diambil menggunakan kuesioner dengan menggunakan wawancara serta metode angket untuk formulir estimated food record selama $3 \times 24$ jam. Observasi pada penelitian ini menggunakan kuisioner dengan Teknik wawancara untuk karakteristik karyawan seperti usia, jenis kelamin dan pengetahuan, faktor ekonomi seperti pendapatan, faktor social seperti pemilihan makan dan gaya hidup, faktor perilaku seperti frekuensi makan dan waktu makan. Sedangkan untuk formulir estimated food record digunakan teknik angket atau responden menulis sendiri sisa makan selama $3 \times 24$ jam.

\section{Analisis Data}

Data yang didapat dari formulir estimated food record akan digunakan sebagai total food loss and waste (FLW). Total food loss and waste (FLW) akan dianalisis secara manual dengan melihat sisa makanan mulai dari makan pagi hingga malam dalam satuan gram sesuai dengan satuan bahan penukar gizi. Selanjutnya seluruh data akan dianalisis menggunakan SPSS Versi 20 untuk melihat hubungan faktor karakteristik karyawan, faktor ekonomi, faktor sosial dan faktor perilaku terhadap total food loss and waste (FLW). Uji yang digunakan adalah uji Chi square karena data penelitian ini berskala kategorik. Penelitian ini juga sudah mendapatkan persetujuan dari Komisi Etik
Penelitian Universitas Esa Unggul dengan nomor kaji etik 0156-21.156/DPKEKEP/FINAL-EA/UEU/VI/2021.

\section{HASIL DAN PEMBAHASAN}

Karakteristik Karyawan, Faktor Ekonomi, Faktor Sosial, Faktor Perilaku dan Food Loss and Waste (FLW)

Responden merupakan karyawan aktif perusahaan PT CJM di wilayah Kota Tangerang. Berikut hasil distribusi frekuensi karakteristik karyawan (umur, jenis kelamin, dan pengetahuan), faktor ekonomi (pendapatan), faktor sosial (pemilihan makan dan gaya hidup), faktor perilaku (frekuensi makan dan waktu makan), dan total food loss and waste.

Sebagian besar responden berusia 19-23 tahun (71.4\%). Menurut (Subarjo, 2015) bahwa usia karyawan menentukan hasil kualitas kerja jika usia tidak belia maka produktivitas kerja akan berkurang. Selain itu, menurut (Susanti, 2015) menjelaskan bahwa usia dapat memengaruhi kinerja fisiologi tubuh.

Masing-masing responden berjenis kelamin laki-laki dan perempuan (50\%). Perusahaan ini tidak memiliki spesifikasi jumlah terkait jenis kelamin sebab kinerja perempuan sangat dibutuhkan ketika melakukan pekerjaan yang sifatnya detail serta teliti. Selain itu, kinerja laki-laki juga sangat dibutuhkan ketika melakukan pekerjaan yang sifatnya memerlukan fisik 
kuat. Menurut (Kurniawan \& Hamdan, 2021)

menjelaskan bahwa produktivitas kerja lakilaki cenderung tidak menggunakan perasaan dan fisik lebih kuat. Akan tetapi produktivitas kerja perempuan lebih teliti dan sabar.

Tabe1. Distribusi Frekuensi Umur, Jenis Kelamin, Pengetahuan, Pendapatan, Pemilihan Makan, Gaya Hidup dan Frekuensi Makan Frekuensi $\%$

(n)

\begin{tabular}{|c|c|c|}
\hline Umur & & \\
\hline a. Dewasa akhir ( $\geq 24$ tahun) & 24 & $28.6 \%$ \\
\hline & 60 & $71.4 \%$ \\
\hline Jumlah & 84 & $100 \%$ \\
\hline Jenis Kelamin & & \\
\hline a. Laki-laki & 42 & $50 \%$ \\
\hline b. Perempuan & 42 & $50 \%$ \\
\hline Jumlah & 84 & $100 \%$ \\
\hline Pengetahuan FLW & & \\
\hline a. Kurang Baik & 56 & $66.7 \%$ \\
\hline b. Cukup & 22 & $26.2 \%$ \\
\hline c. Baik & 6 & $7.1 \%$ \\
\hline Jumlah & 84 & $100 \%$ \\
\hline Pendapatan & & \\
\hline a. Rendah $(<$ Rp.3.800.000) & 34 & $40.5 \%$ \\
\hline b. Tinggi (> Rp.3.800.000) & 50 & $59.5 \%$ \\
\hline Jumlah & 84 & $100 \%$ \\
\hline Pemilihan Makanan & & \\
\hline a. Kurang Baik & 60 & $71.4 \%$ \\
\hline b. Baik & 24 & $28.6 \%$ \\
\hline Jumlah & 84 & $100 \%$ \\
\hline Gaya Hidup & & \\
\hline a. Tidak Baik & 45 & $53.6 \%$ \\
\hline b. Cukup & 22 & $26.2 \%$ \\
\hline c. Baik & 17 & $20.2 \%$ \\
\hline Jumlah & 84 & $100 \%$ \\
\hline Frekuensi Makan & & \\
\hline a. Kurang Baik & 54 & $64.3 \%$ \\
\hline b. Baik & 30 & $35.7 \%$ \\
\hline Jumlah & 84 & $100 \%$ \\
\hline
\end{tabular}

Lebih dari setengahnya responden berpengetahuan kurang baik (66.7\%). Pengetahuan yang baik terkait FLW menjadikan seseorang lebih memahami bahwa kebiasaan FLW akan berdampak buruk pada lingkungan sekitar. Menurut penelitian (Pavone et al., 2019) menjelaskan bahwa kurangnya pengetahuan terkait limbah makanan akan berdampak pada jumlah emisi gas rumah kaca dan sumber makanan zat gizi sehingga bisa mempengaruhi terjadinya FLW.

Sebagian besar pendapatan responden yang dimiliki $59.5 \%$ termasuk kedalam kategori tinggi yaitu (>Rp.3.800.000). Menurut penelitian (Mandasari, 2018) bahwa pendapatan upah/gaji bisa mempengaruhi 
terjadinya FLW dikarenakan biaya hidup yang tinggi dapat menyebabkan pembelian makanan yang tidak terkendali akhirnya memicu pemborosan makanan dan keuangan.

Pada faktor sosial meliputi pemilihan makan lebih dari sebagian responden memiliki pemilihan makan kurang baik (71.4\%). Pemilihan makanan merupakan suatu pangan yang dikonsumsi seseorang untuk memenuhi kenginan rasa lapar dan kepuasan emosional atau selera. Jika seseorang salah dalam memilih makanan akan menimbulkan terjadinya FLW. Menurut penelitian (Ariesta, 2019) menjelaskan bahwa ketidaksesuaian makanan akan mempengaruhi daya nafsu makan seseorang.

Separuh responden memiliki gaya hidup tidak baik $(53,6 \%)$. Gaya hidup responden yang kurang baik seperti membeli makanan trending dikarenakan hawa nafsu dan memesan makanan dengan aplikasi online secara berlebih. Hal itu dapat terjadi ketika responden pada saat WFH untuk menghilangkan rasa kejenuhan mereka melakukan pemesanan makanan untuk dijadikan pendamping pada saat bekerja. Menurut penelitian (Septiansari, Dela, 2021) menjelaskan bahwa pada masa pandemi Covid-19 karyawan saat melakukan WFH lebih sering belanja atau memesan makanan menggunakan aplikasi online shop.

Pada faktor perilaku meliputi frekuensi makan sebanyak $64.3 \%$ responden memiliki frekuensi makan kurang baik. Frekuensi makan responden yang kurang baik seperti dalam seminggu sekitar 2-3 kali menyisakan makanan. Hal itu terjadi karena batas daya tahan tubuh sudah tidak mampu untuk menerima makanan kembali. Menurut penelitian (Mandasari, 2018) menjelaskan bahwa FLW dapat terjadi jika frekuensi makan berlebih membuat makanan dapat terbuang lebih banyak dikarenakan batas daya tahan dan terlalu banyak porsi makanan.

Tabel 2. Distribusi Frekuensi Waktu Makan

\begin{tabular}{lccccccc}
\hline Waktu Makan & $\begin{array}{c}\text { Waktu Yang } \\
\text { ditetapkan }\end{array}$ & \multicolumn{2}{c}{$\begin{array}{c}\text { Tidak Tepat } \\
\text { Waktu }\end{array}$} & \multicolumn{2}{c}{ Tepat Waktu } & \multicolumn{2}{c}{ Jumlah } \\
\cline { 3 - 8 } & & $\mathrm{n}$ & $\%$ & $\mathrm{n}$ & $\%$ & $\mathrm{n}$ & $\%$ \\
\hline Sarapan Pagi & $06.00-08.00$ & 40 & 47.6 & 44 & 52.4 & 84 & 100 \\
Makan Siang & $12.00-13.00$ & 12 & 14.3 & 72 & 85.7 & 84 & 100 \\
Makan & $18.00-20.00$ & 26 & 31.0 & 58 & 69.0 & 84 & 100 \\
Malam & & & & & & &
\end{tabular}

Pada Tabel 2 menjelaskan jika waktu makan responden seperti sarapan pagi didapatkan $52.4 \%$ responden tepat waktu sementara $47 \%$ lainnya tidak tepat waktu. Pada makan siang didapatkan $85.7 \%$ responden tepat waktu sedangkan pada saat 
waktu makan malam hari sebanyak 69\% responden tepat waktu. Menyajikan makanan diwaktu yang tepat serta jarak waktu yang sesuai meliputi sarapan pagi, makan siang dan makan malam dapat mempengaruhi habis atau tidaknya makanan (Puspita,et al 2011).

\begin{tabular}{|c|c|c|}
\hline & $\begin{array}{l}\text { Frekuensi } \\
\text { (n) }\end{array}$ & $\%$ \\
\hline \multicolumn{3}{|c|}{ Total Food Loss and Waste } \\
\hline a. Sedikit $(\leq 29$ gr $)$ & 48 & $57.1 \%$ \\
\hline b. Banyak (> 29 gr) & 36 & $42.9 \%$ \\
\hline Jumlah & 84 & $100 \%$ \\
\hline \multicolumn{3}{|c|}{ Rincian Total Food Loss and Waste } \\
\hline \multicolumn{3}{|l|}{ Makanan Pokok } \\
\hline a. Sedikit ( $\leq 13$ gr) & 49 & $58.3 \%$ \\
\hline b. Banyak (> 13 gr) & 35 & $41.7 \%$ \\
\hline Jumlah & 84 & $100 \%$ \\
\hline \multicolumn{3}{|l|}{ Lauk Hewani } \\
\hline a. Sedikit ( $\leq 5$ gr) & 49 & $58.3 \%$ \\
\hline b. Banyak (> 5 gr) & 35 & $41.7 \%$ \\
\hline Jumlah & 84 & $100 \%$ \\
\hline \multicolumn{3}{|l|}{ Lauk Nabati } \\
\hline a. Sedikit $(\leq 4,5$ gr $)$ & 53 & $63.1 \%$ \\
\hline b. Banyak (> 4.5 gr) & 31 & $36.9 \%$ \\
\hline \multicolumn{3}{|l|}{ Sayuran } \\
\hline a. Sedikit ( $\leq 6$ gr) & 46 & $54.8 \%$ \\
\hline b. Banyak (> 6 gr) & 38 & $45.2 \%$ \\
\hline Jumlah & 84 & $100 \%$ \\
\hline
\end{tabular}

Tabel 3. Distribusi Frekuensi Total dan Rincian Food Loss and Waste

Total food loss and waste (FLW) responden sebanyak $42,9 \%$ menyisakan banyak makanan dan $57.1 \%$ menyisakan sedikit makanan. Dikategorikan baik jika kurang dari sama dengan rata-rata sisa total food loss and waste yaitu 29 gram berarti responden menyisakan sedikit makanan sementara dikategorikan tidak baik jika lebih dari rata-rata sisa total food loss and waste yaitu 29 gram yang berarti responden banyak menyisakan makanan. Menurut (Balaga anjarwati, 2021) menjelaskan bahwa FLW dikatakan baik jika sisa makanan kurang dari sama dengan mean (rata-rata food loss and waste).
Rincian total food loss and waste berdasarkan sisa makanan pokok sebanyak $58.3 \%$ responden menyisakan sedikit makanan dan $41.7 \%$ banyak menyisakan makanan. Rata-rata makanan pokok yang tersisa adalah nasi. Pada lauk hewani sebanyak $58.3 \%$ menyisakan sedikit makanan dan $41.7 \%$ banyak menyisakan makanan. Lauk hewani yang tersisa seperti jeroan ayam, ayam bagian leher. Sementara lauk nabati sebanyak $63.1 \%$ responden menyisakan sedikit makanan dan $36.9 \%$ banyak menyisakan makanan. Lauk nabati yang tersisa seperti tempe dan oncom. Pada sayuran sebanyak $54.8 \%$ responden menyisakan sedikit makanan dan $45.2 \%$ 
banyak menyisakan makanan. Sayuran yang tersisa meliputi kacang-kacangan, daun melinjo dan melinjo.
Hubungan Karakteristik Karyawan, Faktor Ekonomi, Faktor Sosial dan Faktor Perilaku Terhadap Total Food Loss and Waste (FLW)
Berikut hasil analisis bivariat karakteristik karyawan, faktor ekonomi, faktor sosial, dan faktor perilaku dengan total food loss and waste yang disajikan dalam bentuk tabel .

Tabel 4. Hubungan karakteristik karyawan terhadap Total Food Loss and Waste (FLW)

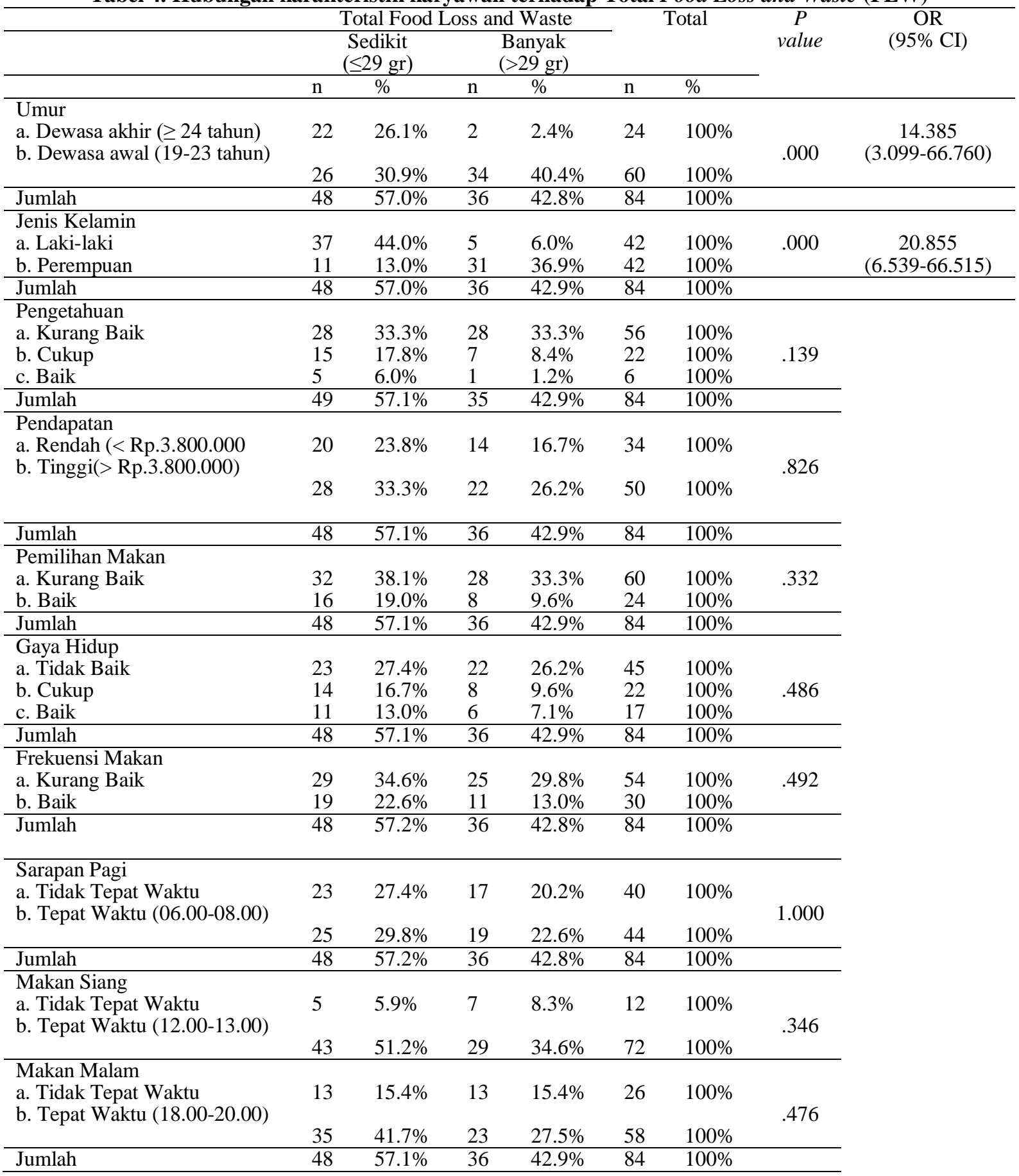


Usia responden dikategorikan menjadi dewasa akhir ( $\geq 24$ tahun) dan dewasa awal (19-23 tahun). Setelah dikategorikan, dapat dilihat berdasarkan Tabel 4 jika responden yang berusia dewasa akhir ( $\geq 24$ tahun) lebih peduli terhadap makanan dapat dibuktikan 22 orang $(26.1 \%)$ sedikit menyisakan makanan sedangkan responden yang berusia dewasa awal (19-23 tahun) masih banyak yang kurang peduli terhadap makanan diperoleh 34 orang $(40.4 \%)$ responden banyak menyisakan makanan diantaranya makanan pokok 37\%, lauk hewani $39.2 \%$, lauk nabati $32.1 \%$ dan sayuran $39.2 \%$. Sehingga hasil analisis uji Chi Square didapatkan p-value sebesar 0,000 dimana hasil nilai tersebut $(\mathrm{p}<0,05)$ disimpulkan terdapat hubungan antara umur dengan total food loss and waste (FLW). Selain itu, dapat dilihat berdasarkan nilai OR sebesar 14.385 dengan 95\% CI antara 3.09966.760 yang berarti jika responden yang berusia 19-23 tahun akan berisiko 14.3 kali lebih tinggi mengalami food loss and waste (FLW) dibandingkan responden berusia $\geq 24$ tahun.

Usia dapat mempengaruhi daya tangkap dan pola pikir seseorang. Semakin bertambahnya usia akan mengalami perubahan terhadap pola pikir, kemampuan kerja, produktifitas kerja dan selera makan. Berdasarkan masalah diatas semakin muda usia responden maka semakin banyak menyisakan makanan hal ini dipengaruhi oleh rasa dan porsi makanan yang dibeli tidak sesuai ekspetasi dan makanan trending yang banyak disebarluaskan di sosial media sehingga membuat seseorang termotivasi untuk melakukan pembelian. Penelitian (Mandasari, 2018) menjelaskan bahwa seseorang yang berusia dewasa awal menghasilkan FLW berkisar 38,60\% karena ketidakpuasan dengan rasa makanan dan $36,84 \%$ lainnya disebabkan karena porsi makanan berlebih yang diberikan penjual. Selain itu, sejalan dengan penelitian (Saragih, B., \& Saragih, 2020) bahwa umur diusia muda sangat berhubungan dengan kebiasaan makan pada saat masa pandemi Covid-19 dikarenakan seseorang sudah mulai bosan dengan makanan dirumah sehingga mereka mulai memesan makanan dari luar akibatnya makanan dirumah berkemungkinan terbuang sia-sia.

Jenis kelamin responden dikategorikan menjadi laki-laki dan perempuan. Setelah dikategorikan, berdasarkan Tabel 4 menunjukkan bahwa perempuan lebih banyak menyisakan makanan diperoleh 31 orang (36.9\%) meliputi makanan pokok $33.3 \%$, lauk hewani $32.1 \%$, lauk nabati $29.8 \%$ dan sayuran $32.1 \%$. Sedangkan laki-laki menyisakan sedikit makanan diperoleh 37 orang (44.0\%). Sehingga didapatkan p-value sebesar 0,000 dimana hasil nilai tersebut $(\mathrm{p}<0,05)$ 
disimpulkan terdapat hubungan antara jenis kelamin dengan total food loss and waste (FLW). Selain itu, dapat dilihat berdasarkan nilai OR sebesar 20.855 dengan 95\% CI antara 6.539-66.515 yang berarti jika responden perempuan akan berisiko 20.8 kali lebih tinggi mengalami food loss and waste (FLW) dibandingkan laki-laki.

Jenis kelamin dapat berpengaruh pada pemilihan makan seseorang. Berdasarkan masalah diatas perempuan lebih banyak menyisakan makanan daripada laki-laki. Hal ini dipengaruhi daya tampung perempuan untuk menerima makanan lebih sedikit dibanding laki-laki, selain itu, lebih mengutamakan hawa nafsu dibandingkan kebutuhannya sehingga membuat perempuan banyak membeli berbagai jenis makanan. Semyung University di Korea Selatan menunjukkan hasil bahwa laki-laki menghabiskan makanan dua kali lebih cepat dibandingkan perempuan. Hal itu dikarenakan laki-laki dapat melahap makanan lebih banyak dan rahang laki-laki lebih kuat saat mengunyah daripada perempuan (Ariesta, 2019). Sejalan dengan penelitian (Afrianto, 2021) bahwa hasil survei tahun 2020 selama masa pandemi Covid-19 menunjukkan jika perempuan lebih sering melakukan pembelian online dibandingkan laki-laki.

Pengetahuan responden dikategorikan menjadi kurang baik, cukup dan baik berdasarkan total jawaban benar yang dijawab oleh responden. Setelah dikategorikan, dapat dilihat Tabel 4 jika responden yang berpengetahuan kurang baik terkait food loss and waste didapatkan 28 orang (33.3\%) masing-masing menghasilkan sedikit dan banyak sisa makanan. Sehingga didapatkan $p$ value sebesar 0,139 dimana perolehan tersebut $(p>0,05)$ disimpulkan tidak terdapat hubungan antara pengetahuan dengan total food loss and waste (FLW).

Pengetahuan yang baik terkait food loss and waste menjadikan seseorang lebih memahami bahwa kebiasaan food loss and waste akan berdampak buruk pada lingkungan sekitar. Berdasarkan masalah diatas responden yang berpengetahuan kurang baik sedikit menyisakan makanan akan tetapi setengah dari responden lainnya masih banyak yang menyisakan makanan. Hal ini bisa saja terjadi karena setengah dari responden berusaha untuk tidak membuang makanan karena hal tersebut termasuk kedalam tindakan mubazir akan tetapi sebagian responden lainnya masih belum menerapkan kebiasaan membungkus makanan atau membawa pulang kembali makanan yang tidak dihabiskan. Hasil peneliti tidak sesuai dengan penelitian (Edoardo, 2019) bahwa pengetahuan secara tidak langsung dapat berpengaruh terhadap FLW dan Penelitian (Radzymińska et al, 2016) menjelaskan jika 
pengetahuan tidak berpengaruh secara signifikan terhadap FLW. Dapat disimpulkan jika pengetahuan tidak bisa dijadikan acuan terjadinya FLW sehingga diperlukan faktor pendukung lain.

Faktor ekonomi meliputi pendapatan responden dikategorikan menjadi pendapatan tinggi (> Rp.3.800.000) dan pendapatan rendah (<Rp.3.800.000). Rata-rata responden pada penelitian ini dibidang produksi, purchase, marketing dan HRD. Setelah dikategorikan, dapat dilihat Tabel 4 menunjukkan bahwa responden yang berpendapatan rendah lebih peduli terhadap makanan dibuktikan 20 orang $(23,8 \%)$ sedikit menyisakan makanan sementara responden berpendapatan tinggi sebanyak 28 orang (33.3\%) sedikit menyisakan makanan akan tetapi sebagian responden masih banyak yang menyisakan makanan yaitu diperoleh 22 orang $(26.2 \%)$ tersisa makanan berupa makanan pokok $27.3 \%$, lauk hewani $22.7 \%$, lauk nabati $21.5 \%$, dan sayuran $29.8 \%$. Sehingga didapatkan hasil analisis uji $C h i$ Square nilai $p$-value sebesar 0,826 dimana hasil tersebut $(\mathrm{p}>0,05)$ disimpulkan tidak terdapat hubungan antara pendapatan dengan total food loss and waste (FLW).

Pendapatan merupakan jumlah uang yang diterima oleh seseorang dalam jangka waktu tertentu dari hasil kerjanya. Pendapatan juga sangat mempengaruhi pola makan dalam memilih makanan terutama pada jumlah makanan yang dikonsumsi seseorang. Berdasarkan masalah diatas responden yang berpendapatan tinggi sedikit menyisakan makanan akan tetapi sebagian dari responden lainnya masih banyak yang menyisakan makanan. Hal tersebut bisa saja terjadi karena beberapa responden hasil upah/gaji dipergunakan untuk ditabung tetapi separuh dari responden masih mengutamakan gengsi sehingga hasil upah/gaji dipergunakan untuk membeli makanan atau barang yang sedang trending dikalangan sosial media. Penelitian (Ariesta, 2019) menunjukkan bahwa pendapatan tidak berpengaruh secara signifikan terhadap FLW. Dapat disimpulkan jika pendapatan tidak bisa dijadikan acuan terjadinya FLW sehingga diperlukan faktor pendukung lain.

Faktor sosial meliputi pemilihan makan dikategorikan menjadi kurang baik dan baik. Setelah dikategorikan, berdasarkan Tabel 4 menunjukkan bahwa responden yang memiliki pemilihan makan kurang baik seperti tidak pernah mengelist daftar makanan yang akan dibeli, menyisakan makanan jika (rasa dan tekstur makanan kurang enak) diperoleh 32 orang $(38.1 \%)$ sedikit menyisakan makanan akan tetapi sebanyak 28 orang (33.3\%) masih banyak yang menyisakan makanan diantaranya makanan pokok $31 \%$, lauk hewani $34.5 \%$, lauk nabati 
$29.8 \%$ dan sayuran $34.5 \%$. Sehingga didapatkan hasil analisis uji Chi Square nilai p-value sebesar 0,332 dimana hasil tersebut ( $p>0,05)$ disimpulkan tidak terdapat hubungan antara pemilihan makan dengan total food loss and waste (FLW).

Pemilihan makanan adalah suatu pangan yang dikonsumsi seseorang untuk memenuhi kenginan rasa lapar dan kepuasan emosional atau selera. Berdasarkan masalah diatas responden yang memiliki pemilihan makanan kurang baik sedikit menyisakan makanan akan tetapi sebagian dari responden lainnya masih banyak yang menyisakan makanan. Hal itu bisa saja terjadi karena beberapa responden berpikir jika membuang makanan termasuk kedalam tindakan mubazir jadi sebisa mungkin dihabiskan walaupun rasa makanan yang dibeli kurang enak akan tetapi separuh responden lainnya beranggapan jika rasa dan tekstur makanan yang dibeli tidak enak akan dibuang begitu saja. Penelitian (Hidayat, et al 2020) menunjukan hasil ( $p>0.05$ ) maka dapat diartikan jika pemilihan makanan tidak berpengaruh secara signifikan terhadap terjadinya food waste. Sejalan dengan penelitian Williams dan Walton tahun 2011 menjelaskan jika rasa, tekstur, penampilan dan pelayanan makanan dapat menyebabkan makanan tersisa (Lestari, Mawar et al, 2020). Dapat disimpulkan pemilihan makanan tidak bisa dijadikan acuan terjadinya FLW sehingga diperlukan faktor pendukung lain.

Gaya hidup responden dikategorikan menjadi tidak baik, cukup dan baik berdasarkan total jawaban yang dijawab responden. Setelah dikategorikan, berdasarkan Tabel 4 menunjukkan bahwa responden yang memiliki gaya hidup tidak baik seperti membeli makanan trending dikarenakan hawa nafsu dan memesan makanan dengan aplikasi online secara berlebih yaitu GoFood, ShoopeFood dan GrabFood diperoleh 23 orang (27.4\%) sedikit menyisakan makanan akan tetapi sebanyak 22 orang (26.2\%) masih banyak yang menyisakan makanan diantaranya makanan pokok $22.7 \%$, lauk hewani $27.3 \%$, lauk nabati $23.8 \%$ dan sayuran $29.8 \%$. Sehingga didapatkan hasil p-value sebesar 0,486 dimana hasil tersebut $(\mathrm{p}>0,05)$ disimpulkan tidak terdapat hubungan antara gaya hidup dengan total food loss and waste (FLW).

Menurut Plummer dalam penelitian (Kaparang M, 2013) gaya hidup merupakan cara seseorang untuk mengidentifikasi bagaimana menghabiskan waktu. Berdasarkan masalah diatas responden yang memiliki gaya hidup kurang baik sedikit menyisakan makanan akan tetapi sebagian dari responden lainnya masih banyak yang menyisakan makanan. Hal tersebut bisa saja terjadi jika beberapa responden masih menerapkan list 
kebutuhan yang akan dibeli ketika belanja online sementara sebagian responden lainnya belum menerapkan list kebutuhan sehingga seseorang akan membeli makanan sesuai dengan trending di sosial media dibandingkan kebutuhannya. Penelitian (Hidayat, et all 2020) menunjukkan jika gaya hidup tidak berpengaruh secara langsung terjadinya food waste karena hasil $(\mathrm{p}>0,05)$.

Faktor perilaku meliputi frekuensi makan dikategorikan menjadi kurang baik dan baik. Setelah dikategorikan, berdasarkan Tabel 4 menunjukkan bahwa sebanyak 29 orang (34.6\%) sedikit menyisakan makanan akan tetapi sebanyak 25 orang (29.8\%) masih banyak yang menyisakan makanan diantaranya makanan pokok $28.7 \%$, lauk hewani $31 \%$, lauk nabati $26.2 \%$ dan sayuran $31 \%$. Frekuensi makan yang kurang baik seperti dalam seminggu sekitar dua sampai tiga kali menyisakan makanan. Sehingga, hasil analisis uji Chi Square nilai p-value sebesar 0,492 dimana hasil tersebut $(p>0,05)$ disimpulkan tidak terdapat hubungan antara frekuensi makan dengan total food loss and waste (FLW).

Menurut DEPKES RI tahun 2014 frekuensi makan adalah seberapa sering seseorang makan dalam sehari meliputi makan pagi, siang, malam dan selingan. Umumnya setiap orang melakukan tiga kali makanan utama yaitu makan pagi, siang dan malam. Berdasarkan masalah diatas responden yang memiliki frekuensi makan kurang baik sedikit menyisakan makanan akan tetapi sebagian dari responden lainnya masih banyak yang menyisakan makanan. Hal tersebut bisa saja dipengaruhi kebiasaan makan responden ketika makan masakan dirumah tekstur dan porsi makanannya sesuai dengan selera, pada saat membeli makanan baik secara online ataupun tidak ternyata tekstur dan porsi makanan tidak sesuai dengan kebutuhan sehingga dapat mempengaruhi responden dalam menghabiskan makanan. Menurut Rumokoy, et al tahun 2017 menjelaskan bahwa kebiasaan makan seseorang dapat berpengaruh pada habis atau tidaknya suatu makanan jika menu, porsi, rasa dan tekstur makanan sesuai dengan orang tersebut maka makanan yang dikonsumsi cenderung dihabiskan (Widyasari, 2021).

Waktu makan responden meliputi sarapan pagi, makan siang dan makan malam. Masing-masing waktu makan dikategorikan menjadi tidak tepat waktu dan tepat waktu. Setelah dikategorikan, dapat dilihat Tabel 4 menunjukkan bahwa responden yang memiliki ketepatan waktu sarapan pagi 25 orang $(29.8 \%)$ sedikit menyisakan makanan akan tetapi 19 orang lainnya (22.6\%) masih banyak menyisakan makanan diantaranya makanan pokok $22.6 \%$, lauk hewani $21.4 \%$, 
lauk nabati $17.8 \%$ dan sayuran $23.8 \%$ sedangkan responden yang ketidaktepatan waktu sarapan pagi 23 orang (27.4\%) menyisakan sedikit makan dan 17 orang lainnya $(20.2 \%)$ banyak menyisakan makanan seperti makanan pokok 19\%, lauk hewani $20.2 \%$, lauk nabati $19.0 \%$ dan sayuran $21.4 \%$. Saat makan siang responden yang memiliki ketepatan waktu makan 43 orang (51.2\%) sedikit menyisakan makanan dan 29 orang lainnya (34.6\%) banyak menyisakan makanan diantaranya makanan pokok $33.3 \%$, lauk hewani $33.3 \%$, lauk nabati $31 \%$ dan sayuran $37 \%$ sedangkan responden yang ketidaktepatan waktu makan siang 5 orang $(5.9 \%)$ menyisakan sedikit makan dan 7 orang lainnya $(8.3 \%)$ banyak menyisakan makanan seperti makanan pokok $8.4 \%$, lauk hewani $8.4 \%$, lauk nabati $6 \%$ dan sayuran $8.3 \%$. Saat makan malam responden yang memiliki ketepatan waktu makan 35 orang (41.7\%) sedikit menyisakan makanan dan 23 orang lainnya (27.5\%) banyak menyisakan makanan diantaranya makanan pokok $28.5 \%$, lauk hewani $26.2 \%$, lauk nabati $22.6 \%$ dan sayuran $28.5 \%$ sedangkan responden yang ketidaktepatan waktu makan malam 13 orang (15.4\%) masing-masing banyak dan sedikit menyisakan makanan.

Sehingga, didapatkan hasil analisis waktu makan meliputi sarapan pagi ( $p$-value 1.000), makan siang (p-value 0.346) dan makan malam ( $p$-value 0.476$)$ dimana hasil tersebut ( $p>0,05)$ disimpulkan tidak terdapat hubungan antara waktu makan dengan total food loss and waste (FLW). Berdasarkan masalah diatas responden yang memiliki ketepatan waktu makan pada sarapan pagi, makan siang dan makan malam sedikit menyisakan makanan tetapi beberapa responden masih banyak yang menyisakan makanan. Hal ini bisa saja terjadi pada saat menyajikan makanan langsung dikonsumsi atau tidak sebab dapat mempengaruhi cita rasa makanan sehingga menentukan abis atau tidaknya makanan. Penelitian Lumbantoruan (2012) dalam (Azizah et al, 2019) menjelaskan bahwa tidak adanya perbedaan sisa makanan antara responden yang memiliki ketepatan waktu makan dan tidak tepat waktu.

\section{KETERBATASAN PENELITIAN}

Lingkungan dalam kondisi tidak baik yaitu pemberlakuan work from home yang disebabkan karena covid-19 terus meningkat sehingga responden yang berada di perusahaan tidak sepenuhnya bekerja secara offline setiap hari.

\section{KESIMPULAN}

Hasil analisis menunjukkan bahwa terdapat hubungan antara umur dan jenis kelamin terhadap total food loss and waste (FLW), serta tidak ada hubungan antara pengetahuan, pendapatan, pemilihan makan, 
gaya hidup, frekuensi makan dan waktu makan terhadap total food loss and waste (FLW).

\section{SARAN}

Untuk karyawan agar lebih bijak dalam melakukan pemesanan makanan secara online dan diusahakan untuk membuat list makanan yang akan dibeli agar meminimalisir terjadinya food loss and waste (FLW).

\section{UCAPAN TERIMAKASIH}

Manuskrip ini telah diikutkan pada Scientific Article Writing Training (SAWT) Batch V Program Kerja GREAT 4.1.e, Program Studi S1 Gizi, FIKES, Universitas Esa Unggul dengan dukungan fasilitator: Dudung Angkasa, SGz., M.Gizi, RD; Khairizka Citra Palupi, SGz., MS; beserta tim dosen prodi Ilmu Gizi lainnya. SAWT Batch IV juga mendapat dukungan dana dari Universitas Esa Unggul.

\section{DAFTAR PUSTAKA}

Afrianto, P. A. (2021). Eksplorasi Kondisi Masyarakat Dalam Memilih Belanja Online Melalui Shopee selama Masa Pandemi Covid-19 di Indonesia. Jurnal Teknologi Dan Informasi Bisnis, 3 No.1. https://doi.org/https://doi.org/10.47233/jteksi s.v3i1.181

Ariesta, dewi sanatasya. (2019). Estimasi Nilai Ekonomi Dari Sisa Makanan (Food Waste) Dan Perilaku Ekonomi Masyarakat Dalam Membuang Sampah Makanan (Studi Kasus : Babakan Raya, Institut Pertanian Bogor). Journal of Chemical Information and Modeling, 53(9), 1689-1699. https://doi.org/10.1017/CBO9781107415324 .004
Azizah, Zulfa Arina; Darni, Joyeti; Damayanti, Yuni Amilia; Naufalina, D. (2019). Perbedaan Tingkat Kepuasan Makan Pasien di Rumah Sakit Bersertifikat Halal Dengan Yang Belum Bersertifikat Halal. Journal Gizi Dan Kesehatan, $\quad 3 \quad$ (1), 25-32. https://doi.org/https://doi.org/10.22487/ghid za.v3i1.17

Balaga anjarwati, S. E. (2021). Hubungan Kualitas Makanan dan Tingkat Stress dengan Sisa Makanan Lunak Pada Pasien Rawat Inap di Rumah Sakit Karya Medika Tambun. ARGIPA (Arsip Gizi Dan Pangan), 6 No.1, 43-51. https://doi.org/10.22236/argipa.v6i1.5310

Edoardo, V. A. S. (2019). Analisis Perilaku Terhadap Food Waste Mahasiswa kampus 4 Universitas Ahmad Dahlan (1). http://eprints.uad.ac.id/14870/

Graham-Rowe, E., Jessop, D. C., \& Sparks, P. (2015). Predicting household food waste reduction using an extended theory of planned behaviour. Journal Resources, Conservation and Recycling, 101, 194-202. https://doi.org/10.1016/j.resconrec.2015.05.0 20

Hidayat, S. I., Ardhany, Y. H., \& Nurhadi, E. (2020). Kajian Food Waste untuk Mendukung Ketahanan Pangan. Journal Agriekonomika, 9 No.2(SINTA 2). https://doi.org/https://doi.org/10.21107/agrie konomika.v9i2.8787 Agriekonomika

Iisnawatia, Rosab, A., Yunitac, D., \& Hartati. (2019). Keputusan Konsumen Menggunakan Jasa Pesan Antar Makanan Online di Palembang. Jurnal Manajemen Dan Bisnis Sriwijaya Vol.17(3), 17(3), 147-157.

Kaparang M, O. (2013). Analisa Gaya Hidup Remaja Dalam Mengimitasi Budaya Pop Korea Melalui Televisi (Studi pada siswa SMA Negeri 9, Manado). Journal Acta Diurna, 2, No.2.

https://ejournal.unsrat.ac.id/index.php/actadi urnakomunikasi/article/view/1138

Kartika, N. E. (2020). Fitur Aplikasi Gojek Favorit Konsumen Pada Saat Pandemi COVID-19 Di Kota Bandung. Jurnal Ilmu Komunikasi, 9(2), 1680-1695.

Kementrian Kesehatan RI. (2020). Panduan Gizi Seimbang Pada Masa Pandemi COVID-19. Kementrian Kesehatan Republik Indonesia, Jakarta.

Kurniawan, Soni Ignatius, Hamdan, M. (2021). Memperkuat Produktivitas: Peran Kepemimpinan Transformasional dan Lingkungan Kerja Pada PT Naga Semut Kebumen. Jurnal Manajemen, 15 (1). 
http://fe.ummetro.ac.id/ejournal/index.php/J M/article/view/533/384

Lestari, Mawar. Agustia, Friska Citra. Betaditya, D. (2020). Pengaruh Modifikasi Standar Makanan Non Diet Terhadap Biaya Makan Yang Terbuang Pada Pasien Geriatri Kelas III di RSUP Dr. Soeradji Tirtonegoro Klaten. Jurnal Gizi Dan Pangan Soedirman, $4 \quad$ No.1. https://doi.org/https://doi.org/10.20884/1.jgp s.2020.4.1.2449

Mandasari, P. (2018). Quantifying and analysing food waste generated by Indonesian undergraduate students. Journal IOP Conference Series: Earth and Environmental Science, 131(1). https://doi.org/10.1088/1755$1315 / 131 / 1 / 012058$

Martinez-Ferran, Fernando de la Guía-Galipienso, Fabián Sanchis-Gomar, H. P.-G. (2020). Metabolic impacts of confinement during the COVID- 19 pandemic due to modified diet and physical activity habits. Journal Nutrients, 12. https://doi.org/https://doi.org/10.3390/nu120 61549

Pavone, L., Lilly-Tjaden, A., Silverman, M., \& Song, H.-J. (2019). Consumer Food Waste and Its Implications for Sustainable Food Management in the University Setting (OR20-05-19). Journal Current Developments in Nutrition, 3, 106. https://doi.org/10.1093/cdn/nzz047.or20-0519

Puspita, Devi Karina; Rahayu, S. R. (2011). FaktorFaktor Yang Berhubungan Dengan Perilaku Menyisakan Makanan Pasien DIIT Diabetes Mellitus. Jurnal Kesehatan Masyarakat, 2, 120-126.

http://journal.unnes.ac.id/index.php/kemas

Radzymińska, M., Jakubowska, D., \& Staniewska, K. (2016). Consumer attitude and behavior towards food waste. Journal of Agribusiness and Rural Development, 1 (39), 175-181. https://doi.org/10.17306/JARD.2016.20.

Saragih, B., \& Saragih, F. M. (2020). Hubungan Berbagai Faktor Dengan Kebiasaan Makan Pada Masa Pandemi COVID-19 (1). https://www.researchgate.net/publication/34 1000876\%0AHUBUNGAN

Septiansari, Dela, H. T. (2021). Pengaruh Belanja Online Terhadap Perilaku Konsumtif Pada Mahasiswa di Masa Pandemi Covid-19. Journal Ekonomi Dan Manajemen Teknologi (EMT), 5 No.1. https://doi.org/https://doi.org/10.35870/emt. v5i1.372

Subarjo. (2015). Faktor-faktor yang mempengaruhi produktivitas karyawan pada CV. Granada. Jurnal Ekonomi Dan Pembangunan, 5, No.2.

http://journal.uad.ac.id/index.php/OPTIMU M/article/view/7883/3940

Sukmi Natalia, S. (2018). Narasi Kuasa Perempuan Pekerja Bisnis Online. Journal Sosiologi Pendidikan Humanis, 3, No.1, 55-65. http://journal2.um.ac.id/index/php/jsph

Susanti, L. (2015). Pengantar Ergonomi Industri (1st ed.). Andalas University Press. http://repo.unand.ac.id/28012/1/Buku Pengantar Ergonomi Industri.pdf

Universitas Indonesia. (2019). Food Waste: The World's Most Unnoticable Sins. Kanopi FEB UI. http://kanopifebui.org/2019/11/07/food-waste-theworlds-most-unnoticable-sins/\#

Widyasari, L. A. (2021). Pengaruh Modifikasi Resep Lauk Nabati Terhadap Sisa Makanan Pasien Diruang Rawat Inap Kelas III RSU.Dr.H. Koesnadi Bondowoso di Kota Bondowoso. Darussalam Nutrition Journal, 5 (1), 21-28. https://ejournal.unida.gontor.ac.id/index.php /nutrition/article/view/4780/9406 